InOedia $\quad \begin{aligned} & \text { InMedia } \\ & \text { The French Journal of Media Studies }\end{aligned}$

7.1. $\mid 2018$

Visualizing Consumer Culture

\title{
Emma Hamilton and Alistair Rolls (eds.), Unbridling the Western Film Auteur: Contemporary, Transnational and Intertextual Explorations
}

Oxford : Peter Lang, 2018

Hervé Mayer

\section{OpenEdition}

\section{Journals}

Electronic version

URL: http://journals.openedition.org/inmedia/1344

DOI: 10.4000/inmedia.1344

ISSN: 2259-4728

Publisher

Center for Research on the English-Speaking World (CREW)

\section{Electronic reference}

Hervé Mayer, «Emma Hamilton and Alistair Rolls (eds.), Unbridling the Western Film Auteur:

Contemporary, Transnational and Intertextual Explorations », InMedia [Online], 7.1. | 2018, Online since 20 December 2018, connection on 24 September 2020. URL : http://journals.openedition.org/inmedia/ 1344 ; DOI : https://doi.org/10.4000/inmedia.1344

This text was automatically generated on 24 September 2020

(C) InMedia 


\section{Emma Hamilton and Alistair Rolls (eds.), Unbridling the Western Film Auteur: Contemporary, Transnational and Intertextual Explorations}

Oxford : Peter Lang, 2018

Hervé Mayer

\section{REFERENCES}

Emma Hamilton and Alistair Rolls (eds.), Unbridling the Western Film Auteur:

Contemporary, Transnational and Intertextual Explorations, Oxford: Peter Lang, 2018

This new publication on the Western genre is both a homage to a seminal book of Western film studies, Horizons West by Jim Kitses (1969), and a reappraisal of a dated concept of film studies, that of the auteur, which was at the heart of Kitses's book (whose original edition was unequivocally subtitled Studies of Authorship within the Western). The editors of Unbridling the Western Film Auteur sought to reclaim the interest of applying auteur theory to the Western genre and reconfigure the meanings of auteurism by taking into account the most recent developments in Western film studies, namely transnationalism and intertextuality. The finished volume is an elevenchapter, 235-page collection of articles refining the concept of auteurism in the Western from various refreshing perspectives: genre theory, adaptation theory, actorial studies, or transnational film studies. The first of these chapters introduces the volume by laying out its theoretical framework and clarifying its intended purpose to "explor[e] and analys[e] a theoretical concept that - like the Western film genre itself has been declared 'dead', only to rise up again in new and innovative ways as a framework through which to examine film and filmmakers" (1). 
2 Emma Hamilton and Alistair Rolls, editors of Unbridling the Western Film Auteur, start their volume with an introducing chapter entitled "Editors on Auteurs: Thoughts on Auteurism from the Frontier", in which they retrace the development of auteurism in film studies and connect it with contemporary film theory and Western film studies. They argue that auteurism is a fruitful concept to explore essential themes of film analysis such as genre hybridity, the interplay of national and transnational identities, intertextuality and originality, or the complexity of production and reception processes. If Jim Kitses understood the Western genre, with its intertextual conventions and symbolic potency, as "supplement[ing] the power of the author to express his singular vision of American society" (13), the contributions to Unbridling the Western Film Auteur "render a more complex portrait of the Western auteur" (14) and explore what happens to the Western and Western auteurship when the genre is displaced across generic, media, or geographical borders.

3 The next chapter, entitled "The Star Auteur: Jimmy Stewart Out West" and written by Alex Davis, expands the notion of the auteur as director to include that of the star as auteur by examining James Stewart's portrayal of the cowboy figure across the works of directors famously associated with auteurship in the Western (Anthony Mann, John Ford and, to a lesser extent, George Marshall). Davis argues that Stewart's polarized persona and penchant for the innovative in his Western films allowed him to mirror the changing mood of American politics across three decades and shape the development of the genre towards revisionism. If the article's broad reliance on reflection theory and evolutionist genre theory does not serve a better understanding of the Western and its relation to American politics, the argument about Stewart's auteurship within the genre, as produced by the actor's performance and publicity and recognized by the audience, although superficially discussed, sheds light on Stewart's career and invites further research on the actor and other Western stars as auteurs.

4 Tom Ue's next contribution, "Pastiche, Genre and Violence in Quentin Tarantino's Inglorious Basterds", explores Tarantino's use of his auteur status to question genre conventions and provoke the viewer to engage critically with the film and its ethical implications. The article discusses the combination of pastiche and generic motifs with a film-within-the-film structure as challenging the viewer to reflect upon her or his enjoyment of genre conventions and ideologies. The theoretical framework of the article (psychoanalytic film theory) and method (use the screenplay to analyze the film) fail to convince, and the concept of auteur is virtually absent from, and eventually irrelevant to, the discussion.

Chapter 4 is Emma Hamilton's own contribution to the volume entitled "Probably a White Fella': Rolf de Heer, The Tracker and the Limits of Auteurism", and analyzes the extent to which Dutch-Australian director Rolf de Heer's auteur status in Australian cinema both fits within, and exposes the limits of, traditional definitions of auteurism. Hamilton's nuanced discussions of de Heer's film as both an "artefact of the time" and an "active shaper of that time", of the film combining de Heer's aesthetic and historical vision with other authorial perspectives (those of Indigenous actor David Gulpilil and Indigenous singer Archie Roach), and of the ethical problem of the white auteur expressing marginalized voices, seamlessly illustrate the interest of applying auteur theory to the Western and vindicate the volume's perspective.

6 In the next contribution, "The Post-apocalyptic Frontier: Reappropriating Western Violence for Feminism in Mad Max: Fury Road", Matthew Carter analyzes the genre 
hybridity of Australian-born director George Miller's film as "re-envisioning the Western by promoting a gendered transformation of the patriarchal-capitalist social relations that produce violence" (87). Carter's contribution gives a clear view of existing research on genre hybridity and applies it efficiently to its reading of Fury Road, while discussing the notion of the auteur in relation with socio-historical contexts of production and expanding it to include groups of films and the specific systems of relations they can create (through a discussion of the Mad Max franchise).

In "Narrative (Il)logic and the Problem of Character Motivation in Sergio Corbucci's Revenge Westerns", Marek Paryz focuses on Corbucci's unconventional use of the revenge motif to bring out an essential lack of logic behind heroic attitudes. The author's analysis of Django, Navajo Joe and The Great Silence is descriptive and takes for granted Corbucci's auteur status rather than use it as a resource in the demonstration, but the discussion of Corbucci's dissection of Western conventions through plot devices remains interesting in understanding the director's contribution to the genre.

The seventh chapter, Lee Broughton's "Adaptation, Transculturation and the Western Auteur: Louis L'Amour, Peter Collinson and The Man Called Noon", deals with the problem of 'national identity' in a transnational production (British/Spanish/Italian production of an American book). Though the film has been associated to spaghetti Westerns and identified with its director's vision by critics, Broughton argues that it bears the attributes of British Westerns that preceded it ("gothic elements and strong and active women", 126) and "can legitimately be categorized as a British Western" too (142). The comparison of the film's aesthetics and plot with L'Amour's novel underlines the flow of Italian and American Western influences across borders, as well as the restructuration of the source material to fit a specifically British brand of Westerns and reflect British socio-political concerns around gender equality.

9 Maria Ioniţă's contribution to the volume, "Auteurism versus Genre in the Romanian New Wave: Radu Jude's Interpretation of Western Tropes in Aferim!", approaches the Romanian director's 2015 genre fare as unsettling the distinction between aesthetic value and political commentary commonly enforced by Romanian critics since the late 1990s to claim "a more politically and socially engaged space for Romanian auteurs" (145). While efficiently discussing Aferim!'s innovative relation to the American Western, to the Romanian Western and historical epic traditions, and to Romanian New Wave auteurism, the article also raises the traditional opposition of genre and auteurism to demonstrate how Jude's film can provide a form of reconciliation.

10 Chapter 9, entitled "Auteur is French for Author, too: Translating Other Afterthoughts Inspired by King Vidor's Duel in the Sun into French Literature", is a collective contribution written by Alistair Rolls, Emma Hamilton and Clara Sitbon. It focuses on the relation of Duel in the Sun to Boris Vian's L'Automne à Pékin and, more largely, on the mapping of the American Western onto France and Paris onto the Western, revealing "the potential of the classic Western always to be something, somewhere else" (165). The authors argue that Vian's adaptation of Duel in the Sun into L'Automne à Pékin produced a French Western that asserted French autonomy over American cultural influence. The article raises questions of reception and appropriation of American Westerns by foreign authors as well as the complex mechanisms of borrowings and intertextuality at play in the transnational cultural influences of reconstruction France. However, the concluding discussion of the novel's relation to the film remains limited, as are the sources available to establish such relation beyond narrative likenesses. 
next chapter, Joyleen Christensen's “'East meets West meets East again': The Good, the Bad, the Weird and the Transnational Dialogue of Auteurs", deals with a complex network of influences between American, Italian and Asian cinemas and the way Kim Jee-woon's 2008 Korean Western innovatively weaves them together, "effectively highlight[ing] the complex nature of auteur-centered transnational cinematic flows" (196). An analysis of characterization, landscape and socio-historical setting serves to map out the threads linking Kim's film to American revisionist, Italian, and Manchurian Westerns as well as Korean and Hong Kong gangster films or Quentin Tarantino's cinema, and sustains a discussion on the film's "political re-allegorization of the Western" (193) to comment upon contemporary Korean nationalist sentiments.

The volume's final chapter, "The Indian Western: Revisiting Sholay and the Dacoit Film as Transnational Exegesis" written by Omar Ahmed, engages with the Indian Dacoit (bandit) films of the 1970s, the most famous of which is Sholay (1975), to present them as "a refashioning of both the Hollywood and Italian Western genres" that reveal the "difficulty of applying the auteur theory to Indian cinema" (203). The author places Sholay as the climax of a second wave of Dacoit films in the early 1970s that was strongly influenced by American revisionist and Italian Westerns, while retaining specific national significance for Indian audiences. The article points out the adaptability of Western conventions and iconography to local cultures, giving those conventions layered meanings as they cross national borders. As such, films like Sholay address their audiences both as national and transnational cultural communities.

The rich and varied perspectives on auteur theory and the Western offered in the volume reveal the usefulness of auteurism in conceptualizing the complex relationship of a film with its sources and its production context. Now that film scholars increasingly agree that films not only reflect upon, but proactively shape, their sociopolitical moment, the concept of auteur, be it defined as an individual vision, a network of individual contributions or even a recognizable signature across films, can help think the film's autonomy from, and impact upon, its context. Although the present contributions very unequally confront the theoretical problems of auteurism, they all agree that for it to have any relevance in contemporary film studies, auteurism needs to be challenged and refined as much as it needs to be saved. As far as Western film studies are concerned, many of the contributions contrast their subtle analyses of post-, hybrid, and transnational Westerns with a rather monolithic understanding of classical American Westerns as standard-bearers of Manifest Destiny, thus adding to a simplistic vision of the genre that originated in the 1960s resistance to the Vietnam war, but most contributions genuinely enlighten the vast networks of intertextual, intermedial and transnational exchanges that inform, and must come to define, the Western genre. 


\section{AUTHORS}

HERVÉ MAYER

Université Paul-Valéry Montpellier 3 